\title{
LEGAL IMPLICATIONS OF LIMITED COMMUNICATION IN THE USE OF NON-CASH FOOD AID CARD
}

\author{
Asnat Juljana Luturmas \\ Universitas Kristen Indonesia Maluku \\ ana.1uturmas19@gmail.com
}

\begin{abstract}
The Kindness family of Grop Mawar, in the village of Latuhalat, helps to feel the difficulty of doing so; first, banking transactions both cash and non-cash, this is largely due to; a). Lower educated elementary school, b). Married at a very young age. Second, do not want to be in contact with a domain of reporting or a legal sphere. Third, culture sends care to the other side, out of shame or insecurity. One of the efforts that can be made to make the families vulnerable to support their own banking transactions is limited communication. Communication is limited, in systemized references through the process of receiving help, with group fellowmen to individual relief recipients, and communicating the means of offense to lack of communication limited to groups and individuals. Breaking laws can occur if the consequences of executing the continuity of the program are inaccurate and inadequately carried out, it is critical that to the extent to which this limited communication is developed, whether by using limited communication, can solve problems in the field, by making up for the mastery of raw procedures of receiving aid that should be used as a handle and communication limited to both the inside and outside of the families of the beneficiaries.
\end{abstract}

Keyword: Poor family, beneficiaries, BPNT, non-cash and Kombo Card 


\begin{abstract}
Abstrak
Keluarga Penerima Manfaat Kelompok Mawar, di Desa Latuhalat, Turut Merasa Kesulitan untuk melakukan ; 1.Transaksi Perbankan baik Tunai maupun non Tunai, hal ini secara menyeluruh disebabkan ; a). Berpendidikan paling rendah SD, b).Menikah diusia yang sangat Muda. 2.Tidak ingin bersentuhan dengan ranah pelaporan atau ranah hukum. 3. Budaya Menitipkan pengurusan Ke pihak lain, atas dasar Malu Hati/Tidak Percaya Diri. Salah satu upaya yang dapat dilakukan untuk membuat keluarga rentan penerima bantuan ini dapat melakukan sendiri transaksi perbankan adalah dengan komunikasi terbatas. Komunikasi terbatas, dalam rujukan tersistem melalui proses penerimaan bantuan, dengan Pendampingan dari Kelompok sampai ke individu Penerima Bantuan, serta Mengkomunikasikan sarana Pelanggaran terhadap kurangnya Komunikasi terbatas di kalangan Kelompok dan individu. Pelanggaran hukum dapat terjadi jika konsekwensi pelaksanaan kelangsungan program tidak tepat sasaran dan tidak dilakukan dengan sebaik-baiknya, menjadi persoalan penting bahwa sampai sejauhmana proses dibangunnya komunikasi terbatas ini berlangsung, apakah dengan menggunakan komunikasi terbatas, dapat menyelesaikan problem yang terjadi di lapangan, diimbangi dengan penguasaan prosedur baku penerimaan bantuan yang harus dijadikan sebagai pegangan dan komunikasi terbatas didalam maupun diluar keluarga penerima bantuan.
\end{abstract}

Kata Kunci: Keluarga Miskin, Penerima Bantuan, BPNT, Non Tunai, Kartu Kombo

ACCEPTED : September $18^{\text {th }}, 2020$ REVIEWED: November $16^{\text {th }}, 2020$ PUBLISHED: Februari $12^{\text {th }}, 2021$

\title{
Introduction
}

Since 2018, the Non-Cash Food Assistance Program or better known as the BPNT / Egg-Rice Program has been implemented by the government (Kasus \& Kota, 2002) (Hotimah \& Koesbandrijo, 2018). The government also gives priority to commodities, meat, nuts, vegetables, and fruits, especially the Mawar group, Latuhalat Village Area, Nusaniwe District, Ambon City (Iii, 2006).

The use of a good information system is the key to the achievement of the Program so that, whether in any area, and in any condition, it is like requiring that any recipient of Non-Cash Food assistance who is a Vulnerable and Registered Family as a Beneficiary, and has BUTAB-KKS (Savings Book- Prosperous Family Card) to which information is available (Volume, 2019). In villages where the head of the 
family generally has a job as a fisherman, such as in Latuhalat Village, the head of the family earns a living by fishing in the sea and then markets it in the center of Ambon City as a location for buying and selling fish. This location is approximately $9 \mathrm{Km}$ from Latuhalat Village.

The use of the Non-Cash Food Assistance Program facilities is more in touch with the Banking application known as the EDC Machine (Program et al., 2016). This machine can only be found at Brilink Agents, because the agent has been registered periodically in certain banking systems (Handayani, 2011). Access to obtain or view Non-cash Banking transactions cannot use an ATM machine. however, transactions can only be carried out at a bank that has more functions to carry out banking activities in the form of cash specifically, and other uniqueness (Rahmadani, 2019) (Galik et al., 2018).

EDC machine specifications available at Brilink Agents are found at several points in the beneficiary's living area which also has internet access nearby, so that there is a direct connection to the Non-Cash Food Social Assistance transaction center. The internet factor is also an important point so that transactions can be carried out well (Volume, 2019). Because the barcode of the Non-Cash Food Assistance Card has certain specificities, the transaction process cannot be carried out at any bank. The card, which is often referred to as the Prosperous Family Card, or known as the Combo Card, can only be accessed through four banks, namely BRI, BTN, BNI and Mandiri. people often call it "Bank Himbara" (Rahmadani, 2019).

The BPNT program, is a new program, which until now, still has to be socialized together, to achieve conducive conditions in the field (Simamora et al., 2017). This is because the use of this Non-Cash Food Assistance Card is not yet known to be used as; 1. Banking Transaction Tools (saving, sending money / transfer, etc.), 2. Non-cash Transaction Tools (checking the nominal / amount of non-cash assistance, as social assistance funds which previously amounted to Rp. 110,000, - until now amounting to Rp. 200,000), 3. As an Identity for Non-Cash Food Assistance Program Participation (Kasus \& Kota, 2002).

In addition, each Access to Non-Cash Food Assistance has a field responsible person, namely the District Social Welfare Officer (TKSK). 
In their duties, the Sub-district TKSK is represented by 1 (one) person for several villages and sub-districts within the District (B et al., 2018). A Sub-District Social Welfare Worker (TKSK) is someone who is given the task, function and authority of the Ministry of Social Affairs and / or provincial social services / agencies, district / city social services / agencies for a certain period of time to carry out and / or assist in the implementation of social welfare according to with the assignment area in the district. Hopefully, the establishment and assignment of TKSK can increase community participation in the implementation of social welfare at the sub-district level; in addition, the realization of coordination, integration, and synchronization of programs and activities for administering social welfare at the sub-district level; and the establishment of cooperation and synergy between the social welfare implementation program and other development programs at the subdistrict level.

In the process of receiving the benefits of the BPNT Program, there were obstacles that made it difficult for residents to receive this assistance. Like the beneficiary families of the Mawar Group, as the beneficiary of the BPNT Program in Latuhalat Village, they also find it difficult to do several things related to the benefits of the BPNT Program. The difficulties include: cash and non-cash banking transactions. Regarding this obstacle, there are several things that cause such as the lowest elementary school education, marriage at a very young age, unwillingness to come into contact with the reporting or legal realm and the culture of entrusting management to other parties, on the basis of shame / insecurity (Eksistensi et al., 1966).

One of the efforts to overcome obstacles related to the process of receiving the benefits of the BPNT Program that can be done to make vulnerable families in beneficiaries of this assistance is by limited communication in conducting banking transactions (Simamora et al., 2017). Limited communication in systemized referrals through the process of receiving assistance with assistance from the group to individual beneficiaries begins with communicating the means of violation of the lack of limited communication among the group and the individual (Hikmawati, 2015). 
Limited communication in systemic referrals through the process of receiving assistance with assistance from groups to individual beneficiaries begins with communicating the means of violation of the lack of limited communication among the group and the individual. Of course, a lack of limited communication among groups and individuals can provide opportunities for errors that can lead to lawlessness. This could trigger obstacles for BPNT Program recipients in the process of banking transactions up to program implementation.

Constraints in violation of the law can occur if the consequences of the continuity of the program are not right on target and are not carried out as well as possible. In anticipation of this, it becomes an important issue that to what extent the process of building limited communication takes place, whether by using limited communication and whether this limited communication can solve problems that occur in the field (Hukum et al., 2016) (Issue, 2018). In the implementation of limited communication within and outside the beneficiary's family, it is balanced with mastery of standard procedures for receiving assistance that must be used as a guide, so that for this problem and study, the title is "legal implications of limited communications in the use of non-cash food aid card" with a research study on vulnerable families in the Mawar Group in Latuhalat Village, Nusaniwe District, Ambon City.

\section{Research Method}

This study uses a research flow consisting of several steps as a research method. The research flow used consisted of problem identification, literature study, data collection, group analysis, limited communication patterns and finally journaling. The research flow is described as follows:

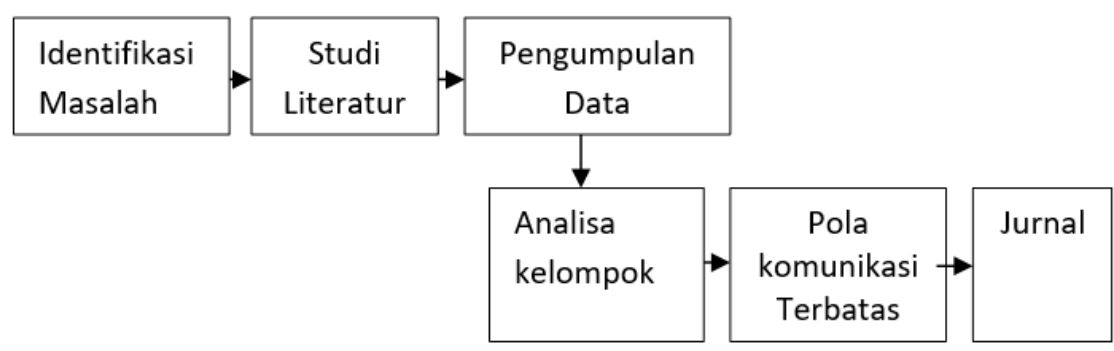

Picture 1. Research Flow 
Problem identification is the first step in this research. The stage of identifying the problem is carried out in order to understand the problem to be studied, so that the analysis stage and the Limited Communication Patterns do not come out of the problem being studied. This stage, will study and understand the guiding and reference theories from journals and also the internet regarding the legal rules used, to complement the vocabulary of concepts and theories, so that they have a relevant scientific foundation. In supporting materials, the data required in this study use several methods, namely observation and interviews.

Observation is research conducted by conducting direct observation to determine the development of information and control of the program, as well as the use of Non-Cash Food Assistance Cards, both in groups, as well as individuals / individuals, including Distribution agents. The purpose of this observation is to determine the implications of limited communication for beneficiaries / vulnerable families / KPM.

In the interview technique, the Assistance of Non-Cash Food Assistance, the Mawar Group, as a Group of Prosperous Family Card Recipients for Non-Cash Food Aid, is carried out directly by the Agent and Distribution Bank. This is done to obtain information or direct explanation from the parties concerned about the limited communication process and the constraints faced in this study.

Analyzing the problem, which is an obstacle to increasing the use of Non-Cash Food Assistance Cards for the Mawar group in Latuhalat Village, Nusaniwe District, Ambon City. In addition, an analysis of the information obtained in a systematic manner from groups, individuals, Facilitators / TKSK and agents is carried out in the form of an Information Process flow.

This study uses this method in the form of a Limited Communication flow. This Limited Communication Method has not been widely used by researchers, but has been commonly used in civilization, both in politics, as well as in the lives of Indigenous Peoples, so that all supporting components are both organs (TKSK Facilitators, Rose Groups / Individual KKS Users / and Agents, as well as The government as an umbrella for the Non-Cash Food Assistance Program) is interrelated or influences. The research materials included the flow of 
the assistance information process, the structure of the group administrator and the limited communication flow that lives in the community.

\section{Results and Discussion}

Help Information Process Flow

The flow that occurs in the field, before the Vulnerable Beneficiary Family or what is called KPM receives a Family Sejartera Card / KKS / Combo Card, Pay data has been provided according to the name and address, which is carried out by a mechanism in OMSPAN, which is directly related to NIK / KPM Identity Number, so that based on the payment data, the data has been recorded and valid, then confirmed to the bank for printing the Savings Book and Social Assistance Card / KKS, and for the final stage, coordinating with the village so that there is no Human Error in the distribution of BUTAB / KKS.

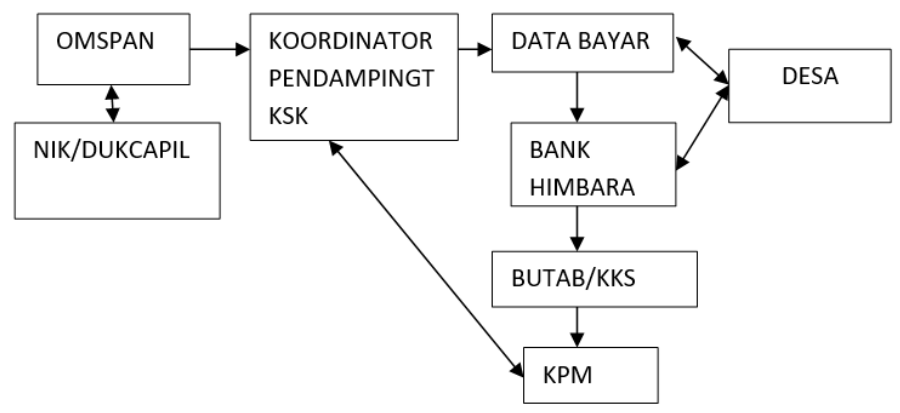

Picture 2. Help Information Process Flow

\section{Group Management Structure}

The reality that occurs in society is that to get good information, a Group Structure is needed that can accommodate the dissemination of information as a whole, so that there are no violations that have legal implications, on the communications made. Through an examination of the existence of this structure, it is able to explain the dissemination and absorption of information through limited communication. 


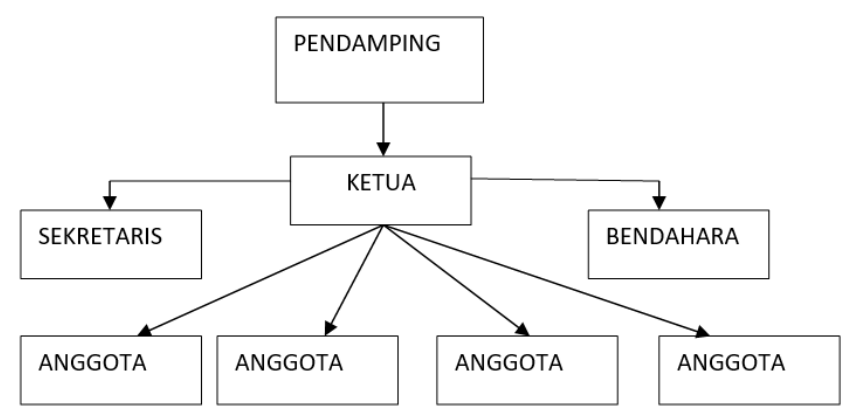

Picture 3. General Structure Group of Mawar

Limited Communication Flow that lives in the Community

It is realized that communication is the oldest science that dominates all civilizations, which currently has extraordinary developments and is supported by technological sophistication so that facilities can be carried out, especially in the process of receiving BPNPT Program assistance. This also happened to the Mawar Group, Latuhalat Village, Nusaniwe District, Ambon City. The following is an interview session with the beneficiaries of the non-cash food assistance program to find out the implications of limited personal communication.

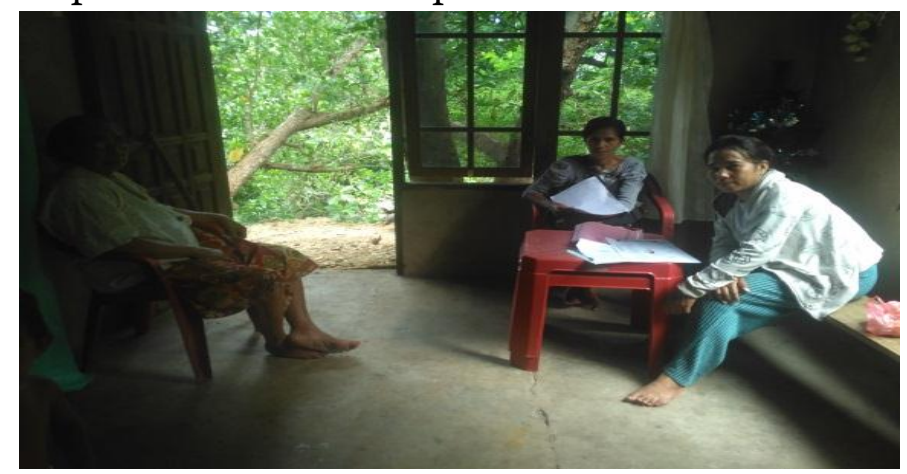

Picture 4. Interview Session With Beneficiaries Of The Non-Cash Food Assistance Program 


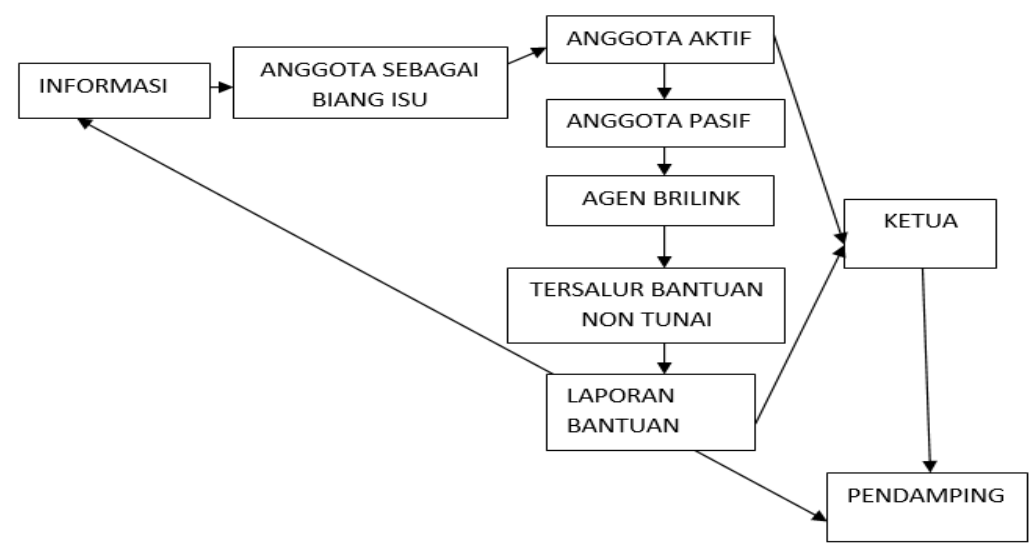

Picture 5. Limited Communication Flow That Lives in The Community This Limited Communication flow starts from the companion's information, which is passed on to the members as the source of the issue to the active members with the knowledge of the Group Leader. Then, based on this message, the Group Leader mobilizes passive / uninformed members to go to Brilink agents and access their own Non-Cash assistance. So, the process of distributing social aid in the field which is also known to the Chairman, can run by reporting the distribution process to the Facilitator. This will show the implications of the success of Limited Communication carried out with the main actors, who are members who act as issue leaders in the group. In addition, this also minimizes Assistance Cards that are misused by Group Members to become Active using the Aid Facilities at Brilink Agents. This process also trains skills in conducting banking transactions, due to the frequency of limited communication, and the practice of taking social aid.

Group Communication made a lot of progress, especially in delivering systematic programs, especially in distributing Non-Cash Food Assistance, see below, which is a direct interview process with the Mawar Group in Latuhalat Village, Nusaniwe District, Ambon City. This process has provided a solution to the problem of using KKS Cards / Combo Cards / Non-Cash Food Assistance Cards which are felt to be quite difficult to do in people's lives and daily lives. Generally, they are fish sellers and earn a living as fishermen. The following is documentation of interviews with beneficiaries of the non-cash food 
assistance program to determine the implications of limited communication in groups.

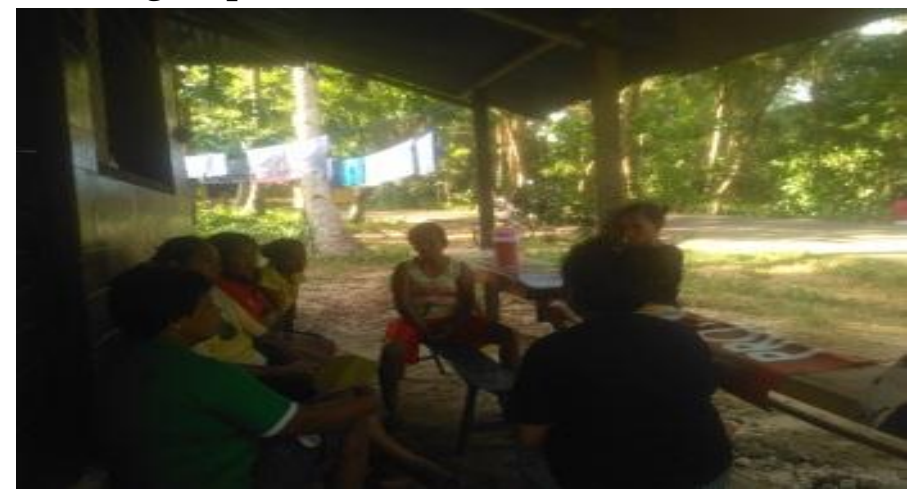

Picture 6. Interviews with Beneficiaries of the Assistance Program Non-Cash Food to Know the Implications of Limited Communication in The Group

\section{Limited Communication Legal Implications}

At this stage, the results of coordination with the bank and direct interviews with beneficiaries (figure 7) have found that limited communication is very helpful in reducing violations of beneficiary rights. Of course, this can have legal implications for unauthorized holders and users of Social Aid Cards.

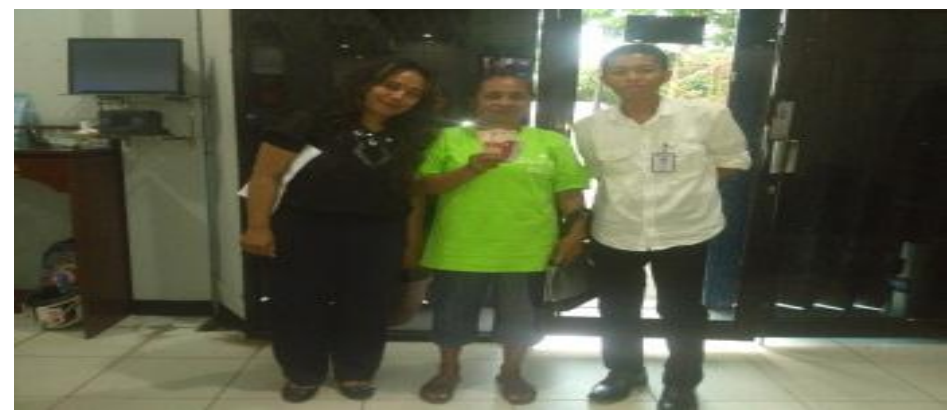

Picture 7. Checking Bank Balances Activity

In addition, in implementing limited communication is very helpful in checking and conducting banking activities, without worrying about fraud. In Figure 7, even non-cash aid card holders can carry out banking transactions, both saving and checking balances. Limited communication, is the best thing that is appropriate for use by the Bank, as well as the Beneficiary Party, in addition, for the Implementing Assistants of the Non-Cash Food Aid Program. 


\section{Limited Communication to vulnerable families who receive Non-Cash Food assistance in using KKS Cards}

The implementation of communication is limited to vulnerable families of non-cash assistance recipients using the KKS Assistance Card in the Mawar Group, Latuhalat Village, Nusaniwe District, Ambon City has a good influence on the independence of using the KKS Card, this is due to the lack of knowledge and lack of communication built into the group, so that only some people in the group actively receive assistance using KKS Cards, while others prefer to leave it with other people to make transactions.

Based on interviews and direct observation Limited communication needs to be improved in understanding the use of information dissemination in using Non-Cash Food Assistance Cards, so that information is not yet optimal, thus efforts are needed to improve limited communication to vulnerable families who receive Non-Cash Food assistance by using Bansos cards Mawar Group, Latuhalat Village, Nusaniwe District, Ambon City.

\section{Non-Cash Food Aid Receipt Process}

In implementing the process of receiving non-cash Food assistance, it has a considerable influence on the rose group, in the Latuhalat village in practice. Based on the results of interviews and observations in the group, the distribution of Non-Cash Food assistance has been maximized. However, from several members in the group, some still left their assistance cards for other members to take. this is because some are sick, and some are still awkward in conducting Non-Cash banking transactions. Also, there are those who think that it should be taken by someone who has a better understanding of banking activities. So that from one to 2 aid recipients must share a portion of their assistance receipts with others. This is always done because it is seen as a tradition of saying thank you. The clerk without thinking if it is adjusted to the implementation has violated the provisions stipulated in implementing this program.

These results provide important information. based on interviews and direct observation within the group, the use of the Non-Cash Food Aid Card either individually or in banking areas has an effect on the need 
to be directly assisted in conducting banking transactions. Because the process of withdrawing non-cash food assistance using social assistance cards is not optimal, so the process of direct control and assistance is needed, especially for the Mawar Group.

\section{Legal Implications of Limited Communication for vulnerable families of Non-Cash Food aid recipients in the Mawar Group}

Latuhalat Village has very good implications. The lack of knowledge of banking activities and the fear of trying to use aid cards by some people in the group prove that the need for legal understanding is needed in limited communication. Limited communication will remove the worries and fears that each member has in general. The group will better understand how important it is to carry out banking transactions alone without the help of other parties.

Based on the results of interviews in the group, there are factors related to receiving assistance, including: individual individuals and agents accompanied by direct observation, the culture of community life that still appreciates one's good deeds by giving rewards for good treatment done. Therefore, these cultural nuances often create a dilemma when the process of implementing legal sanctions is carried out. Silence and not expressing opinions and preferring to affirm that the act of giving some assistance because it has helped is seen as the highest reward even though this is a violation in conducting banking transactions.

Thus, the determinants of communication are limited to increasing the use of non-cash food assistance cards, with more emphasis on the intention of violations to be carried out legally based on the applicable norms of the application of laws and regulations. This action is intended for both good and specific matters concerning the regulations for the distribution of non-cash food aid as well as the law which indicates a criminal act or an act that can be criminalized. Failure to represent a favor transaction to someone could violate regulations on the basis of embezzlement, as well as theft. Other things that can be seen legally when unwittingly have legal implications, namely: the assistance card is used by the entrusted party for other purposes, besides its use, for example being mortgaged, it can also be done when a non-cash food aid withdrawal is made, due to lack of information, provide assistance card 
pin code, so that other people can easily access the location of assistance collection without being noticed by the assistance card owner.

\section{Conclusion}

From this research, it can be concluded that: 1). The process of using the Group Information system with a combination of structures can overcome the weaknesses of each member of the group who are not active and become active in conducting Non-Cash Food Aid transactions. 2) Limited Communication is a reference to prevent legal implications in society as well as in groups. Efforts to train the group to be more independent. In the future, this communication must be monitored in a direction, because the information is used and disseminated to members who act as the source of the issue. In this regard, acting beyond the trust of both the Facilitator and the group is strongly discouraged. Because the person as the starter will feel, his status exceeds the Chairman. This is what is very feared, therefore there must also be an effort to inform the members about what is the core of the discussion together to discuss future matters. 3) The legal implications of limited communication are good as long as the information is not misused. If limited communication contains political intentions or eats up group togetherness, it will not result in change. On the other hand, this will result in a quarrel, therefore there needs to be an effort or attitude of recorded reporting which is very much needed in the process of receiving this program assistance.

\section{Bibliography}

B, C. N. N., Destiwati, R., Ilmu, S., Komunikasi, F., \& Telkom, U. (2018). Pola Komunikasi Virtual Grup Percakapan Komunitas Hamur "HAMURinspiring" Di Media Sosial Line. Jurnal Manajemen Komunikasi, 3(1), 34-50.

Eksistensi, M., Seni, S., Angelica, V. O. X., \& Kalesaran, E. R. (1966). Peran komunikasi organisasi dalam meningkatkan eksistensi sanggar seni vox angelica.

Galik, K. G. (2018). Efektivitas Pelaksanaan Program Bantuan Pangan Non Tunai (BPNT) Di Kelurahan Gulak Galik Oleh (Anisa Rahma Dini, Yunisca Nurmalisa, Abdul Halim). Hasil Telusur Hasil Web Efektivitas Pelaksanaan Program Bantuan Pangan Non Tunai. Jurnal. Fkip.Unila.Ac.Id >, 12. 
Handayani, T. (2011). Membangun Komunikasi Efektif Untuk Meningkatkan Kualitas Dalam Proses Belajar Mengajar Tutut. Fakultas Tarbiyah IAIN Raden Fatah Palembang, XVI(TA'DIB), 30 .

Hikmawati, E. (2015). Ketepatan Sasaran Penerima Bantuan Sosial Jaminan Kesehatan. 0274, 13.

Hotimah, S., \& Koesbandrijo, B. (2018). Implementasi Peraturan Menteri Sosial Nomor 11 Tahun 2018 Tentang Penyaluran Bantuan Pangan Non Tunai. Jurnal Penelitian Administrasi Publik. 5(2), 1211-1216.

Hukum, J. I., Universitas, P., \& Kuala, S. (2016). Tanggung jawab pemerintah terhadap pemberian bantuan hukum bagi masyarakat miskin di provinsi aceh 1). Jurnal Ilmu Hukum Pascasarjana Universitas Syiah Kuala P, 4(1), 25-28.

Iii, B. A. B. (2006). Azizah Zahra Ulfah, 2016. Analisis Hojodoushi Iku Dan Kuru Sebagai Ungkapan Yang Menyatakan Aspek Bentuk Teiku Dan - Tekuru. Bandung: Universitas Pendidikan Indonesia.

Issue, L. (2018). Optimalisasi Pemberian Bantuan Hukum Demi Terwujudnya Access to Law and Justice Bagi Rakyat Miskin Optimization of Legal Assistance to the Fullest Access to Law and Justice for. Jurnal Konstitusi, 14(1), 23.

Kasus, S., \& Kota, D. I. (2002). Implementasi Program Bantuan Pangan Non Tunai. 0042, 122-129.

Program, M., Ilmu, D., Universitas, H., \& Jakarta, T. (2016). Urgensi Penyelenggaraan Bantuan Hukum Bagi Masyarakat Miskin Oleh Pemerintah Daerah(Urgency of Legal Aid for the Poor by Local Government ). Jurnal Sosial \& Budaya Syar-, 3(2), 137-152.

Rahmadani, M. I. (2019). Informasi Pendataan Keluarga Penerima Manfaat ( KPM ) Bantuan Pangan Non Tunai (BPNT) Pada Dinas Sosial Kota Jambi. Jurnal Manajemen Sistem Informas, 4(4), 444-454.

Simamora, N., Ulva, M., \& Sihombing, S. (2017)."Peranan Komunikasi Antar Pribadi Dalam Kepuasan Berinteraksi Di Kalangan Mahasiswa Fakultas Ekonomi Dan Ilmu Sosial USM- Indonesia Program Studi Ilmu Komunikasi Universitas Sari mutiara Indonesia Jurnal Len. Jurnal Lensa Mutiara Komunikasi, 13. Jurnal Lensa Mutiara Komunikasi ISSN : 2579-8332.

Volume, S. P. (2019). Implementation Of Non-Cash Food Assistance Through. Spirit Publik, 14 (April), 81-93. 